\title{
From Tehran to Helsinki: the International Year of Human Rights 1968 and State Socialist Eastern Europe
}

\author{
Ned Richardson-Little \\ University of Erfurt \\ ned.richardson-little@uni-erfurt.de
}

\begin{abstract}
When the United Nations proclaimed 1968 to be the International Year of Human Rights, the official goal was to promote the adoption of the recently created human rights Covenants around the world. Instead of compelling the Eastern Bloc to accept liberal democratic conceptions of rights, however, it acted as a catalyst for the genesis of state socialist conceptions of human rights. Eastern Bloc elites claimed these rights were superior to those in the West, which they argued was beset by imperialism and racism. Although some within Eastern Europe used the Year as an opportunity to challenge state socialist regimes from within, the UN commemoration gave socialist elites a new language to legitimize the status quo in Eastern Europe and to call for radical anti-imperialism abroad. While dissent in the name of human rights in 1968 was limited, the state socialist embrace of human rights politics provided a crucial step towards the Helsinki Accords of 1975 and the subsequent rise of human rights activism behind the Iron Curtain.
\end{abstract}

\section{Keywords}

human rights - communism - decolonization - United Nations - Helsinki Accords 


\section{Introduction ${ }^{1}$}

The United Nations proclaimed 1968 to be the International Year of Human Rights and around the world this was celebrated with lofty pronouncements by heads of state, public protests, and of course, commemorative stamps. In state socialist Eastern Europe, the Year of Human Rights did not have the same dramatic impact as the Helsinki Accords would in 1975, yet there were some behind the Iron Curtain who used it as a point of reference to criticize the state. Across the Eastern Bloc, the International Year served as a crucial moment when human rights became part of the mainstream of state socialist ideology and diplomacy. Rather than the International Year serving to disseminate a universal or global vision of human rights, in the Eastern Bloc it acted as a catalyst for the generation of new state socialist conceptions of human rights, which were asserted both at home and internationally. The commemoration of human rights by the UN created wave of creative illiberal translations of international norms into the language and norms of the Eastern Bloc as the commemorative year sparked the engagement with human rights by intellectuals and in the popular media of Eastern Bloc countries. Instead of fostering mass dissent, the UN Year acted instead to give Eastern Bloc elites a new language to legitimize the state socialist status quo in Eastern Europe and to call for radical anti-imperialism abroad.

Although the International Year of Human Rights was once almost completely forgotten, it has been recently rediscovered by international historians and its meaning fiercely contested: ${ }^{2}$ For some historians, this year was a failure: a UN conference held in Tehran glorified the rule of the dictatorial Shah of Iran and many other authoritarian leaders who were celebrated as "development dictators." ${ }^{3}$ Others, however, see the International Year as representative of the

1 I would like to acknowledge the support of the Leverhulme Trust in their funding of the "1989 after 1989. Rethinking the Fall of State Socialism" project (RL-2012-053).

2 Before the wave of scholarship on the topic beginning in 2008, the International Year was virtually forgotten. See Normand, R., and S. Zaidi. Human Rights at the UN: The Political History of Universal Justice (Bloomington: Indiana University Press, 2007).

3 On the side of authoritarian hijacking, see Burke, R. "From Individual Rights to National Development: The First UN International Conference on Human Rights, Tehran, 1968." Journal of World History 19 (3) (2008): 275-96; Moyn, S. Last Utopia: Human Rights in History (Cambridge: Belknap, 2010), 126-29; Thompson, A.S. "Tehran 1968 and Reform of the UN Human Rights System." Journal of Human Rights 14 (1) (2015): 84-100; Burke, R. "How Time Flies': Celebrating the Universal Declaration of Human Rights in the 196os." The International History Review 38 (3) (2016): 394-420. 
vital role of small post-colonial nations in reviving human rights on the global stage after it had fallen into the shadows following the passage of the Universal Declaration of Human Rights in $1948 .{ }^{4}$ In this recent scholarship, however, the Soviet Union and the role of the Eastern Bloc has been largely ignored. Roland Burke and Steven Jensen agree that the Tehran Conference went poorly for the USSR: it was forced to work with the US in a "makeshift détente" to prevent the Third World from completely dominating the event, and it was pressured into signing on to the International Covenant on Civil and Political Rights against its own interests, thus paving a path towards the dissident activism of the $1970{ }^{5}{ }^{5}$ For the rest, the Soviets are little more than spoilers, undermining Western initiatives due to their inherent antipathy to human rights. ${ }^{6}$

This article argues that the International Year of Human Rights served as a crucial moment of transformation in state socialist Eastern Europe by normalizing human rights. This normalization took two forms: first, amongst the elites of the Eastern Bloc and second, within the international human rights system itself. Before the Second World War, the Soviets had ignored the idea of human rights entirely, maintaining Karl Marx's critiques of "so-called rights of man," which they alleged only advanced hypocritical bourgeois interests in the name of humanity. In the post-war era, it was sometimes used as a diplomatic weapon against the West, but without being truly internalized into socialist ideology beyond the work of some scattered academics and functionaries. ${ }^{7}$ Only as a result of the International Year did it become a discourse employed across the Eastern Bloc by state socialist elites, who claimed to stand for a superior kind of "socialist human rights" at home where capitalist exploitation had been abolished.

4 On the side of Global South revival, see Jensen, S. The Making of International Human Rights: The 196os, Decolonization, and the Reconstruction of Global Values (Cambridge: Cambridge University Press, 2016). Skinner, R. "The Dynamics of Anti-Apartheid: International Solidarity, Human Rights and Decolonization." in Britain, France and the Decolonization of Africa: Future Imperfect? eds. Andrew W.M. Smith and C. Jeppesen (London: UCL Press, 2017), 111-30.

5 Burke, "From Individual Rights to National Development," 292; Jensen, The Making of International Human Rights, 178 .

6 See for example, Snyder, S.B. "The 1968 International Year for Human Rights: A Missed Opportunity in the United States." Diplomatic History 42 (5) (2018), 831-58. Ridder, P. "Tehran, 1968: International Conference on Human Rights." In Online Atlas on the History of Humanitarianism and Human Rights, eds. F. Klose, M. Palen, J. Paulmann, and A. Thompson, Leibniz Institute of Global History and Centre for Imperial and Global History, Exeter University (2015). Available at http://hhr-atlas.ieg-mainz.de/index.

7 On Eastern Bloc and human rights, see Richardson-Little, N., H. Dietz, and J. Mark. "New Perspectives on Socialism and Human Rights in East Central Europe since 1945." East Central Europe 46 (2-3) (2019). 
On the international stage, the Eastern Bloc states were also normalized within the UN system as it came to focus on racism, colonialism, and Apartheid. The states targeted most for their human rights violations in 1968 were South Africa, Rhodesia, Israel, and fascist Spain, not the Eastern Bloc states, nor the "development dictatorships" in the recently decolonized Global South. Although few states shared the belief of socialist elites that the Eastern Bloc represented global champions of human rights, the Soviet Union and its allies were regarded as useful allies to the decolonized world. The failure of the International Year to advance the cause of human rights universalism was, for state socialist countries, a triumph of pluralism in a world divided by ideology. In the eyes of state socialist elites, the International Year of Human Rights confirmed the place of the Eastern Bloc on the world stage while casting a light onto the failings of the human rights claims of the West and its allies.

In this way, the International Year played a crucial role in the realization of the Helsinki Accords of 1975 by first making the field of human rights appear to be terrain where the Eastern Bloc could profitably engage with the West, rather than an inherently threatening field of international affairs. Although the International Year was initiated by diplomats seeking to advance the position of the Global South and supported in the West by those aiming to spread liberal democratic conceptions of rights, as a global event organized via the United Nations, state socialist elites were also able to appropriate its message for their own purposes. Eastern Bloc diplomats were ultimately not successful in convincing the international community that state socialism was indeed the vanguard of the international human rights movement, but in attempting to do so and internalizing this message, there were long-term domestic consequences that would only emerge years later with the rise of dissident movements demanding political reform.

\section{From Insurgency to Normalization}

For the Soviet Union and its Eastern Bloc allies, the field of human rights at the United Nations was not initially a site of great success. As Mark Mazower has argued, the UN was conceived of as a means of preserving Empire in the face of the disruptions of the Second World War, and the creation of the Universal Declaration of Human Rights (UDHR) in 1948 reflected this ideological orientation. ${ }^{8}$ Some Marxist legal theorists in the Soviet Occupied Zone of Germany

8 Mazower, M. No Enchanted Palace: The End of Empire and the Ideological Origins of the United Nations (Princeton: Princeton University Press, 2009). 
and in Hungary had begun to contend with the meaning of human rights from a socialist perspective at this time, but the UsSR did not bring such ideas to the deliberations over the UDHR. ${ }^{9}$ Although the Soviets did not have a developed counter-conception of human rights, they did aim to use the UN as a forum to advance anti-colonialism and to ensure that such a system would not create an international system that would interfere with their own internal affairs. ${ }^{10}$ The USSR and its socialist allies at the early UN pushed for the inclusion of the right to self-determination in the UDHR, a right that had been part of the Atlantic Charter of 1941 and the UN Charter itself only three years earlier. Outmatched diplomatically, the Soviets were defeated and led a bloc-wide abstention on the final vote. The only others to abstain were the Kingdom of Saudi Arabia, in protest of sections on religious freedom, and South Africa, in objection to the sections on racial equality. ${ }^{11}$

Over the next decade, however, the steady increase in the number of postcolonial states began to change the calculus of decolonization and human rights at the UN. British and French officials found themselves no longer leading on the issue of human rights, and anti-colonial activists and statesmen were elevated by the rapid admission of so many former colonies, which outnumbered the Western members by 1960. But the cooperation between the East and the South was not actually a partnership in full and state socialist leaders remained uncomfortable with human rights rhetoric outside of accusing the West of hypocrisy. ${ }^{12}$ Soviet leaders and diplomats opted to promote "socialist legality," not "socialist human rights" when contrasting their system to the perfidy of the imperialist West. ${ }^{13}$ In 1960 , the USSR was one of the sponsors of The Declaration on the Granting of Independence to Colonial Countries and Peoples - which declared colonialism itself a human rights violation - but the emergent Afro-Asian Bloc voted against a Soviet draft, which was deemed overly polemical against the West rather than focused on realistically achieving

See Polak, K. "Gewaltteilung, Menschenrechte, Rechtsstaat: Begriffsformalismus Und Demokratie." Einheit 7 (December 1946); Imre, S. Az emberi jogok mai értelme (Budapest: Hungária, 1948).

10 Mazower, M. "The Strange Triumph of Human Rights, 1933-1950." The Historical Journal 47 (2) (2004), 379-98.

11 Morsink, J. The Universal Declaration of Human Rights: Origins, Drafting, and Intent (Philadelphia: University of Pennsylvania Press, 1999), 21-28.

12 Engerman, D.C. "The Second World's Third World." Kritika: Explorations in Russian and Eurasian History 12 (1) (2011), 183-211.

13 Amos, J. "Embracing and Contesting: The Soviet Union and the Universal Declaration of Human Rights, 1948-1958." in Human Rights in the Twentieth Century, ed. S.L. Hoffmann (Cambridge: Cambridge University Press, 2010), 147-65. 
self-determination. ${ }^{14}$ In that same year, when Soviet leader Nikita Khrushchev addressed the General Assembly in New York and called upon it to respect human rights, he explicitly cited the UN Charter and its references to the equality of states, while ignoring the UDHR. ${ }^{15}$

The International Year of Human Rights had been first proposed by Jamaica, and it aimed to encourage states to promote the cause of human rights, educate citizens on the contents of the UN human rights system and encourage states to sign the two Human Rights Covenants - one on political and civil rights and the other on economic, social and cultural rights - which had been finalized in $1966 .{ }^{16}$ In contrast to the 1950 s when the Soviets were insurgents fighting against the domination of the UN system by the colonialist West, in the lead up to International Year celebrations, the Eastern Bloc states were now treated as normal participants in the international human rights system. René Cassin, one of the drafters of the UDHR and an anti-Communist leftist, now praised the Soviet contribution to the debates over the Declaration twenty years earlier, omitting the bloc-wide abstention: "The most rapid progress, however, was made on the Declaration itself and special attention was given, at the suggestion of the Soviet delegate, Ambassador Alexander Bogomolov, to those Articles dealing with economic, social and cultural rights." ${ }^{17}$ When the first "United Nations Prizes in the Field of Human Rights," were awarded in 1968, the Ukrainian representative to the Human Rights Commission Petr Nedbailo was one of those honored alongside Cassin as well as the Chairman of Inter-American Commission on Human Rights and - posthumously - Chief Albert Luthuli, President of the African National Congress, and former American First Lady Eleanor Roosevelt. ${ }^{18}$

The normalization of state socialist Eastern Europe came as the result of the collapse of the original vision of universal rights formulated by the United Nations in 1948 and its replacement by a more pluralistic system that emerged due to rise of post-colonial power at the UN. As Roland Burke has argued "the carefully calibrated web of universally applicable, interdependent, inherent

\footnotetext{
14 Klose, F. Human Rights in the Shadow of Colonial Violence: The Wars of Independence in Kenya and Algeria (Philadelphia: University of Pennsylvania Press, 2013), 225-26.

15 "Speech by Nikita Khrushchev at the 869th Plenary Meeting of the 15th Session of the United Nations General Assembly." September 23, 1960, History and Public Policy Program Digital Archive, United Nations Document A/PV.869, 65-84. Http://digitalarchive. wilsoncenter.org/document/155185.

16 Jensen, The Making of International Human Rights, chap. 3.

17 Cassin, R. "How the Charter on Human Rights was Born." unEsco Courier (January 1968), 5 .

18 Burke, “'How Time Flies," 412-13.
} 
freedoms had been fully dismembered," between the fifteenth anniversary of the UDHR in 1963 and the International Year of Human Rights in 1968. American officials lamented this shift and the seeming lack of interest from other states in the problem of state socialist violations of human rights: "at the moment little or no concern is shown in the $\mathrm{UN}$ on the human rights issues other than racial discrimination. Thus, there is little consideration of such questions as antisemitism in the Soviet Union." ${ }^{19}$ More than just a single-minded focus on racism, decolonization and the rise of the Afro-Asian Bloc had steered the UDHR from the idea of liberal universalism, and many observers, including in the West, now saw the implementation of human rights as a pluralistic matter in a global community dependent on diverse local social, economic, and political systems.

An indication of this pluralistic shift can be found in the comments of Sean MacBride, the Chairman of the Amnesty International Executive and also the Secretary-General of the International Commission of Jurists (ICJ). The ICJ was founded in 1952 as an anti-communist competitor to International Association of Democratic Lawyers, but when MacBride took over in 1963, the organization became less overtly anti-communist. ${ }^{20}$ Shortly before the International Year, MacBride described a global hierarchy of human rights violations: at the worst end of the spectrum was "massive, systemic and permanent violations of human rights," as the result of policies willfully adopted by a state - namely South Africa and Rhodesia. This focus on racist colonial states reflected the priorities of the UN where more than half of all meetings held by the Commission on Human Rights in 1968 were devoted to discussing Rhodesia and South Africa. ${ }^{21}$ The next worst category included the "medium" or "semi-permanent" violators in the form of right-wing dictatorships such as Spain or Portugal. MacBride argued that while the Eastern Bloc would have been in the worst category in the Stalinist era, these states could now be categorized as having "comparative freedom," but with "systemic violations of particular rights, such as freedom of association, freedom of expression, freedom of criticism." Eastern Europe was now a problematic region, but not one that inherently and massively violated the rights of its citizens. ${ }^{22}$

\footnotetext{
19 Snyder, "The 1968 International Year for Human Rights." 4.

20 For an example of ICJ anti-communist human rights campaigning, see International Commission of Jurists. The Berlin Wall: A Defiance of Human Rights (Geneva: International Commission of Jurists, 1962). On MacBride's role in realigning the ICJ, see Tolley, H.B. The International Commission of Jurists: Global Advocates for Human Rights (Philadelphia: University of Pennsylvania Press, 2010), 107-8.

21 Jensen, The Making of International Human Rights, 176.

22 Eide A., and A. Schou, eds. International Protection of Human Rights (New York: Interscience Publishers, 1968), 151.
} 
Not only were perceptions from the West softening on the role of the Eastern Europe, state socialist elites now began to see themselves as the global champions of the new anti-imperialist human rights order at the United Nations. In an internal report from Foreign Affairs Minister Andrei Gromyko to the Central Committee on the subject of the International Year he noted the leadership role of the USSR in working with the Third World on the 1960 Declaration on Colonialism as evidence that the Soviets had a strong record of promoting human rights at the United Nations. ${ }^{23}$ This viewpoint was shared by a new generation of experts across the Bloc: as Bulgarian legal scholar Anguel Chichkov argued, only socialism provided the solution to colonialism through human rights: "In the presence of socialism, the application of the right to selfdetermination leads to the realization of human rights in all social areas. In general, the world socialist system has had a truly revolutionary effect on the national liberation movement." ${ }^{24}$ Although the USSR and its allies were in the position of following the initiatives of the Third World, on the subject of human rights they now claimed to lead, by dint of their revolutionary ideology.

Rather than treating the International Year of Human Rights as a threat to domestic stability, Eastern Bloc elites saw it as an opportunity to both advance socialist conceptions of human rights and to reveal the mass violations committed by the capitalist West. In internal discussions with the Central Committee, Foreign Minister Gromyko argued that the goals of the USSR would be to "propagate the Soviet realization of workers' rights and to expose the imperialistic policy of genocide in Vietnam, in the Middle East and the social and material political instability of Greece," and the "violations of democratic freedoms and the rights of workers in capitalist countries," in general. ${ }^{25}$ Many of the states in the Eastern Bloc had their own particular priorities in engaging with human rights beyond the general line set in Moscow: as Czechoslovakia entered into a period of liberalizing reforms - the Prague Spring - it sought to use the Year as a chance to legitimize its program of "socialism with a human face." After Warsaw Pact forces invaded in August, the hardliner government then aimed to use the event to legitimize its roll-back of those very reforms. The Polish government, which was engaged in an antisemitic purge of state

23 Gromyko to Central Committee (April 2, 1968). Originally located in RGANI, Fond 89/ Opis 19/ Delo 3, Archives of the Soviet Communist Party and Soviet state microfilm collection, Reel 1.995, Hoover Institution Archives.

24 Chichkov, A. "Le droit à l'autodétermination des peuples coloniaux et le respect des droits de l'homme." La République Populaire de Bulgarie et les droits de l'Homme, ed. E. Kaménov (Sofiâ: Association Bulgare de Droit International, 1970), 182.

25 Gromyko to Central Committee (January 9, 1968) Originally located in RGANI, Fond 89/ Opis 19/ Delo 43, Archives of the Soviet Communist Party and Soviet state microfilm collection, Reel 1.995, Hoover Institution Archives. 
institutions, used the International Year as a chance to sign the UN's Convention on the Elimination of Racial Discrimination (CERD) in order to deflect international criticism. ${ }^{26}$

East Germany in particular embraced the International Year due to its unique position as the only Eastern Bloc state that was not recognized beyond the socialist world due to a West German diplomatic blockade. ${ }^{27}$ Neither Germany had been allowed entry into the UN, and as a result they were not eligible to sign the human rights Covenants, but the Politburo believed that if the GDR could convince the developing world that its domestic politics were in line with international human rights norms, this would affirm the GDR's claim to act as the legitimate German state on the world stage. The GDR expanded on its already longstanding conflict over human rights with West Germany to try to appeal directly to the Third World as an ally in the fight for self-determination in order to possibly find a means of gaining acceptance as a member of the international community. ${ }^{28}$ According to a Politburo directive, it was crucial to show the world that "socialist humanism is the embodiment of human rights and to unmask the misuse of the idea of 'human rights' that drives the implementation of West German imperialist class interests." The Socialist Unity Party (SED) would also highlight West Germany's refusal to renounce its "imperialistic" claims to sovereignty over East German territory in order to draw parallels between the plight of the colonized world and the isolation of the GDR. ${ }^{29}$

At the highpoint of the UN Year - the International Conference on Human Rights held in Tehran from April 22 to May 12 - the Eastern Bloc was not, however, particularly successful in advancing these goals. Soviet declarations were overshadowed by a speech by the Czechoslovakian reformist delegate who spoke of political deficits under socialism. Although state socialist elites spoke glowingly of the rising power of the Third World, the reality of an international conference dominated by small post-colonial states was ultimately distressing for Moscow. Rather than cede control entirely to the Afro-Asian Bloc, the

26 Stola, D. "Fighting against the Shadows: The Anti-Zionist Campaign of 1968." In Antisemitism and Its Opponents in Modern Poland, ed. Robert Blobaum (Ithaca: Cornell University Press, 2005).

27 Gray, W. Germany's Cold War: The Global Campaign to Isolate East Germany, 1949-1969 (Chapel Hill: University of North Carolina Press, 2003).

28 On SED engagement with human rights before 1968, see Richardson-Little, N. The Human Rights Dictatorship: Socialism, Global Solidarity and Revolution in East Germany (Cambridge: Cambridge University Press, 2020).

29 German Federal Archives (Bundesarchiv - BArch) BArch DY 30/J IV 2/3/1404 Inhaltliche Konzeption für Maßnahmen aus Anlaß des von der unO proklamierten "Internationalen Jahres der Menschenrechte," 1-3. 
Soviets had to work with the United States behind the scenes to ease up on mutual attacks in order to preserve the primacy of the great powers. ${ }^{30}$ For East Germany, which was not allowed to attend the conference, the diplomatic push for recognition also failed and it was unable to convince any states to break ties with the West Germans and recognize the GDR instead. ${ }^{31}$

Yet, looking beyond the awkward backroom maneuvering and the GDR's frustrated hopes for mass recognition, 1968 was not actually a diplomatic disaster for the Eastern Bloc. In advance of Tehran conference, the Soviets had already stalled Western plans to create a High Commissioner for human rights with a counterproposal to create a panel of commissioners representing each world region. Rather than fight for this new position that could enforce a universalist interpretation of human rights, Western states instead opted to abandon the plan entirely. ${ }^{32}$ The Czechoslovakian speech was embarrassing, but the conference remained focused on colonialism, apartheid and racism, instead of international monitoring and enforcement of political and civil rights, which had been sought by Western activists. ${ }^{33}$ The official directive from Moscow for representatives at Tehran was to "amplify the struggle against colonial and imperialist oppression and lawlessness, as well as the propaganda networks on the achievements of socialism fundamental realization of workers' rights." ${ }^{34}$ Writing for the Soviet press, the USSR delegates claimed afterwards that the "socialist countries in the Tehran Conference ensured the anti-imperialist orientation of the work and promoted decision-making aimed against the policy of aggression, racism, and colonialism. During the conference, the aggressive imperialist policies of the United States and other Western states were exposed." At the same time, "the Western powers aimed at creating national bodies and procedures for interfering in the internal affairs of other states, but they did not find support for these measures." ${ }^{35}$ The Soviets were able to walk

$30 \quad$ Burke, "From Individual Rights to National Development." 292.

31 East Germany gained recognition from Cambodia and Iraq in 1969, but this was unrelated to its human rights campaign. Wentker, H. Aussenpolitik in Engen Grenzen: Die DDR Im Internationalen System, 1949-1989 (Munich: Oldenbourg, 2007), 285.

32 Thompson, "Tehran 1968 and Reform of the UN Human Rights System," 89.

33 Whelan, D. Indivisible Human Rights: A History (Philadelphia: University of Pennsylvania Press, 2010), 151.

34 Директивы: Советской делегации на Международной конференции по правам человека (Directives: Soviet Delegation to the International Conference on Human Rights), 1. Originally located in RGANI, Fond 89/ Opis 19/ Delo 3, Archives of the Soviet Communist Party and Soviet state microfilm collection, Reel 1.995, Hoover Institution Archives.

35 В. Чхиквадзе, Я. Островский, «Международная конференция по правам человека» (International Conference on Human Rights), Международная жизнь 8 (1968), 30. 
away from the conference believing their primary goals had been achieved and the aims of the Western imperialists had been thwarted.

The positive inclination towards the International Year can be seen in the Eastern Bloc's collective decision to adopt the UN Human Rights Covenants in 1968. The Soviet Union, Poland and Hungary all signed the two Covenants in March so that their adoption would be recorded in advance of Tehran with Romania lagging behind, offering its signature on June 27. Less than two months after a Warsaw Pact invasion ended the Prague Spring in late August, the new government of Czechoslovakia signed the Covenants on October 7 , and Bulgaria joined suit the next day. Although the GDR was not eligible to sign as a non-member of the UN, on October 9 Foreign Minister Otto Winzer formally committed East Germany to signing the Covenants and other international rights agreements as soon as it was allowed to. ${ }^{36}$

The decision to commit to the UN Human Rights Covenants cannot be dismissed merely as a propaganda exercise. In the case of the GDR, the promise to sign the document was preceded by a nearly year-long bureaucratic review of the Covenants by almost all sections of the East German state apparatus. ${ }^{37}$ All agreed that East Germany was in complete compliance with UN human rights norms, with State Prosecutor Josef Streit arguing that, "the practice of law enforcement organs in the GDR has for a long time corresponded to the basic rights as determined by the UN General Assembly." ${ }^{38}$ By contrast, many non-socialist states were far more hesitant about signing: Spain and Portugal delayed signing the International Covenant on Civil and Political Rights (ICCPR) until 1976 when both countries were in the process of democratizing. The United States, wary of constraints on its sovereignty, waited even longer, and signed only in 1977 when President Jimmy Carter took office. France waited until 1980 to simultaneously sign and ratify the ICCPR, and South Africa did not sign the ICCPR until the end of Apartheid in 1994. For the Eastern Bloc, international human rights represented comparatively safe diplomatic terrain.

$36 \quad$ Political Archive of the Foreign Office (Politisches Archiv-Auswärtiges Amt PA AA) MfAA C 487/76 Winzer to U Thant (October 9, 1968), 1-4.

The departments, organizations and state organs contacted included the League for International Cooperation, the Supreme Court, the Ministry of Justice, the Ministry of Health, the Ministry of Education, the Ministry of Culture, the General State Prosecutor's Office, the State Office for Work, the Ministry of the Interior, the Ministry of Finance, the State Central Administration for Statistics, the Committee for the Protection of Human Rights, the State Office for Job Training, the Ministry of Higher Education and the Ministry for State Security. PA AA, MfAA C 487/76 Vorbereitung des Anschlusses und Beitrittserklärung der DDR an die UN Konventionen.

BArch DP 3/102 Streit to Winzer (December 4, 1967). 
Crucial to the deepening socialist engagement with human rights diplomacy was the development of international legal expertise within the Eastern Bloc. No longer merely operating within socialist academia, Eastern European legal scholars aimed to demonstrate the theoretical legitimacy of socialist human rights and to present themselves as intellectual equals and not mere propagandists for the socialist cause. In the lead up to the International Year, this could be seen at the Nobel Symposium for human rights scholars and practitioners from around the world held in Oslo at the end of 1967. Hungary was represented by Imre Szabó, an orthodox Marxist-Leninist who was the pre-eminent expert in socialist law and human rights in Eastern Europe. Already having published a work on the subject in English for an international audience in $1965,{ }^{39}$ Szabó acted as an impartial legal theorist working from scientific, not ideological principles and used his presentation to outline the theoretical differences between natural law, positivist and socialist theories of human rights. He concluded with an optimistic note that "controversial theories and different approaches exist as to the essence and nature of human rights on the one hand, and possibility of agreement concerning the actual international codification and safeguards of these rights on the other."40 The Czechoslovakian representative, law professor Rudolf Bystricky, challenged Western interpretations of universal human rights, but did not completely reject the universality of human rights obligations. Rather than focusing on ideological divergences between East and West, he encouraged cooperation based on the fact that the developing world was the most deprived of all forms of human rights. "Special responsibility rests on the advanced socialist and capitalist countries, since more than two thirds of the world's technical, economic and scientific potential is in their hands." ${ }^{41}$

In Oslo, the presentations of the socialist representatives were received well and even supported by some of the Westerners. Roger Pinto, a law professor from the University of Paris, was most sympathetic and echoed the Eastern Bloc professors on the need for regional diversity in the realization of universal human rights. He argued that "abusive denunciations" of real or alleged human rights violations in Eastern Europe were counterproductive and likely to "slow down development." Pinto stopped short of endorsing a Marxist interpretation of human rights, but he acknowledged that it was one of the many

\footnotetext{
39 Szabó, I. Socialist Concept of Human Rights (Budapest: Akadémiai Kiadó, 1966).

40 Eide and Schou, International Protection of Human Rights, 45.

41 Ibid., 290.
} 
regional interpretations of the concept that needed to be taken seriously on an intellectual level.

When the International Year of Human Rights arrived soon after the Oslo symposium, the Eastern Bloc states organized a wide variety of their own academic conferences on the subject. In Moscow there was a conference held on human rights in April, Poland held two scholarly seminars on the protection of human rights in December, and Hungary had an academic debate on the domestic defense of civil rights. ${ }^{42}$ The proceedings of a symposium held in Sofia by the Bulgarian International Association for International Law were published only in French so that it would be read in the West. ${ }^{43}$ On a political level, human rights politics were a means of working with the Global South against imperialism, but it was a matter gaining recognition from intellectual elites in the West.

This can be seen most clearly at an international colloquium held at Humboldt University in East Berlin in March 1968, hosted by the Committee for the Protection of Human Rights (CPHR). Founded in 1959, the CPHR had initially been tasked with campaigning for the release of imprisoned communists in West Germany, but by the late 196os its remit had expanded to global human rights. Two of the key members of the Committee, Hermann Klenner and Bernhard Graefrath, were leading experts in the field of human rights. ${ }^{44}$ Rather than simply arrange a meeting of socialist intellectuals, CPHR sought to bring over sympathetic Westerners and to demonstrate the GDR's commitment to human rights first hand. Aiming high, the Committee invited the famed Swedish sociologist Gunnar Myrdal - likely due to his work on race relations in the United States - but he turned them down. More embarrassingly, the General Secretary of the International Federation of Human Rights (FIDH) Suzanne Collette-Kahn refused the invitation on "political-moral" grounds as she would not be permitted to speak out against the existence of the Berlin Wall. In the end, however, they were able to get 34 participants from 12 Western countries (Austria, Belgium, Denmark, Finland, France, Greece, Italy, the Netherlands, Norway, Sweden, the UK and West Germany) to agree to attend in addition to the delegates from across the Eastern Bloc. Several were Communists, but they also included four pacifists, eight social democrats and 11 deemed

42 On Soviet activities, see UNGA Third Committee A/C.3/SR.1623 (November 29, 1968), on Poland see UNGA Third Committee A/C.3/SR.1627, March 12, 1968; on Hungary see UNGA Third Committee A/C.3/SR.1628 (December 4, 1968).

43 Kaménov, La République Populaire de Bulgarie et les droits de l'Homme.

44 Graefrath, B. Die Vereinten Nationen und die Menschenrechte (Berlin: Deutscher Zentralverlag, 1956); Hermann Klenner, Studien über die Grundrechte (Berlin: Staatsverlag der DDR, 1964). 
"bourgeois-liberal progressives." Despite the event's ostensible focus on selfdetermination, only a single attendee from Guyana could be described as coming from the Global South. ${ }^{45}$

The event had been planned to coincide with the final weeks of preparation for a national plebiscite on a new "socialist constitution," and in welcoming guests, Committee Chairwoman Friedel Malter emphasized the importance of the vote that would soon be held as a marker of East Germany's commitment to human rights. She asked the delegates, specifically those from Western Europe, to also experience the preparations for the referendum itself as a kind of triumph for self-determination. ${ }^{46} \mathrm{~A}$ keynote speech given by Hermann Klenner combined cutting criticism of Western hypocrisy on human rights with a total absence of criticism of the GDR or state socialism. He noted that Lyndon Johnson could somehow claim that human rights were fulfilled in the United States, while being "President of the country which is seeking to stifle the human rights of the Vietnamese in a hail of cluster bombs, the country in which the black man is terrorized because of the colour of his skin." West German Foreign Minister Willy Brandt made similar claims even though the "Bonn [constitution] does not even contain the right to work, although the communists, as in Spain, Portugal and Greece - are driven underground and the remnants of democracy are to be delivered up to the choking grip of the military by means of the prepared emergency laws." 47 Klenner then asked the audience "are the declarations of Johnson and Brandt pure deception? Perhaps mixed with self-deception?" In Klenner's presentation, the West was not only the driver of racist imperialism, it was also possibly so deluded it did not realize that it was the villain in the global story of human rights.

In the discussion that followed, none of the visitors expressed anticommunist sentiments, but Roger Pinto - one of the "bourgeois" participants and the French law professor who at Oslo had been open to regional human rights differences in Eastern Europe - voiced some critical opinions. While the reforms underway in neighboring Czechoslovakia showed that MarxismLeninism was not purely dogmatic, he was not convinced by the frantic campaign for the new constitution in the GDR. Allowing public demonstrations and posters only for the "yes" campaign was contrary to the concept of freedom. While Pinto was somewhat supported in this call for increased freedom by a left-wing Italian Catholic participant, the Soviet representative Igor

45 BArch DZ $7 / 69$ Abschlussbericht, 1-4.

46 BArch DZ $7 / 69$ Begrüßungsansprache der Friedel Malter, an die Teilnehmer des internationalen Kolloquiums am 29./30. März 1968, 4. 
Blishchenko did not accept even this mild complaint. Under socialism, he said "they only restrict the freedom of revanchists and war criminals." Disappointingly for the Committee, the only foreign news coverage they received outside the Socialist Bloc was a small article in the party organ of the Finnish Social Democrats, which mentioned Pinto's critical intervention, although it did also praise the East German courts system. ${ }^{48}$ Although Eastern Bloc experts hoped to engage with their Western counterparts as academic equals, the ideological imperatives of the Cold War ultimately overrode such ambitions.

One of the important results of the International Year of Human Rights was the clear increase in the use of the discourse of rights within the Eastern Bloc. In the Soviet Union, popular events were planned for Moscow, Kiev and Minsk to center around both the Day for the Elimination of Racial Discrimination (March 21), which commemorated the Sharpeville Massacre in South Africa, and Human Rights Day (December 10), which marked the twentieth anniversary of the passage of the Universal Declaration. The Central Committee also requested special coverage of the year from the Novosti news agency and the journals International Relations, International Affairs, The New Times, and Soviet State and Law. ${ }^{49}$ Commemorative stamps celebrating the International Year were released by Bulgaria, Czechoslovakia, the GDR, Hungary, and Romania. ${ }^{50}$ In addition to the stamps, the Romanian leader Nicolae Ceauşescu, who until 1968 had practically never spoken on the subject of rights, now delivered speeches with lines such as "It is known that socialism, by abolishing the exploitation of man by man, achieves [the] equality of rights among all citizens." ${ }^{51}$

48 BArch DZ $7 / 69$ Abschlussbericht, 9-12.

49 О мероприятиях по случаю Международного года прав человека (On Events Marking the Occasion of the International Year of Human Rights) (1968 год), 1. Originally located in RGANI, Fond 89/ Opis 19/ Delo 43, Archives of the Soviet Communist Party and Soviet state microfilm collection, Reel 1.995, Hoover Institution Archives.

All Eastern Bloc states used the generic flame design put forward by the UN for commemorative stamps in 1968 except for the GDR, which released a three-stamp set: a hammer and anvil to represent the right to work, a tree and the earth to represent the right to life, and a dove with the sun to represent the right to peace.

$5^{1}$ Speech to the General Meeting of Writers (November 16, 1968) in Ceauşescu, N. Human Rights in the Contemporary World (Bucharest: Editura Politică, 1985), 26. In this collection 
In East Germany, the UN commemoration coincided with the creation of a new "socialist constitution," which was integrated into the international campaign and framed as an achievement of human rights. In his New Year's Address in 1968, SED leader Walter Ulbricht proclaimed:

Our new socialist and humanistic constitution, which is based on respect for human rights and that highest of human rights, the right to peace, which will be the concern of our whole society, is also a fine contribution of the German Democratic Republic to the objective of this "International Year."52

As a result, East German state media was awash with human rights stories in early 1968 and in January alone, the SED's national newspaper Neues Deutschland published 32 articles mentioning human rights. While human rights could not be achieved under the "dictatorship of the monopolies" in West Germany, these articles claimed that East German citizens experienced the "fundamental rights of citizens, such as the right to work, the right to education, the equality of men and women, not just promises on paper."53 To educate the population, a pair of pamphlets was produced by the CPHR, with helpful side-by-side comparisons of the contents of the two UN Human Rights Covenants and the corresponding sections of East Germany law that realized them. ${ }^{54}$

Across the Eastern Bloc, academics produced accessible short books to explain the history of human rights from a socialist perspective to different national audiences. According to one such work by Jacek Machowski, human rights could be traced back to Hammurabi, Cicero, and the "Nemin Captivabimus, ${ }^{155}$ but the modern version was the product of Polish and socialist historical achievements: the Noble Republic was integrated into the

of excerpts of Ceauşescu speaking on rights, there is only a single citation of him using the term rights prior to 1968 .

52 Ulbricht, W. "1968 - Jahr wichtiger Entscheidungen." Neues Deutschland, January 1, $1968,1$.

53 "Verfassung sozialistischer Gemeinschaft." Neues Deutschland, January 5, 1968, 1.

54 Klenner, H. Die politische Bürgerrechte in der DDR (Berlin: Komitee zum Schutze der Menschenrechte, 1967); Büchner-Uhder, W. Sozialistische Menschenrechte in der Deutschen Demokratischen Republik: zum Recht auf Mitwirkung an der Leitung von Staat, Wirtschaft und Kultur durch alle Bürger der DDR (Berlin: Komitee zum Schutze der Menschenrechte, 1968).

55 Machowski, J. Prawa cztowieka: zagadnienia wspólpracy miedzynarodowej (Warszawa: Książka i Wiedza, 1968), 13-14. 
narrative of heroic struggle for progress while the socialist People's Republic "has fought at UN for the extension and strengthening of international cooperation in the field human rights in the spirit of a peaceful principle coexistence of all states with different political, economic and social systems." ${ }^{56}$ In a Hungarian volume from the same year, Imre Szabó traced the history of socialist human rights back to Sophocles, Hugo Grotius and John Locke. ${ }^{57} \mathrm{He}$ emphasized the role of human rights as a site of peaceful co-existence with the West in modern times: "The drafters of the [Universal] Declaration sought first and foremost to create a document acceptable for both capitalist and socialist countries, and it was open to them whether they were signing on a Marxist theoretical basis or based on a bourgeois position," which meant that the rights within could be interpreted according to either the "bourgeois or socialist conception of democracy" 58 For socialist citizens, the message from the state was that human rights were part of their national heritage and an essential element in the ideological project of the present.

\section{5}

Fallout at Home

It is widely assumed that the Helsinki Accords of 1975 played a transformative role in Eastern Europe when state socialists formally agreed to human rights provisions in an international agreement, and in turn, citizens stood up to demand the state fulfil its promises. In 1968, however, Eastern Bloc state extensively used the rhetoric of human rights and signed international human rights treaties with almost no consequences at home. There was little to be seen of the vaunted "boomerang effect" in which promises made at the UN haunted dictatorships, which had cynically hoped to gain victories on the world stage with insincere commitments to human rights. ${ }^{59}$ In Czechoslovakia, the Soviet Union, and East Germany, there were some appeals to human rights, but nothing compared to the explosion of activism that came in the 1970s after Helsinki or in the late 1980 s in the lead up to the fall of the Berlin Wall.

During the Prague Spring the language of human rights was surprisingly absent from the rhetoric of socialist reformers, aside from Rudolf Bystricky's speech at the Tehran Conference, but it did find a foothold among the

\footnotetext{
$56 \quad$ Ibid., 12.

57 Szabó, I. Az emberi jogok. (Budapest: Akadémiai Kiadó, 1968), 14-19.

58 Ibid., 54 .

59 See Risse, T., S.C. Ropp, and K. Sikkink, eds. The Persistent Power of Human Rights: From Commitment to Compliance (Cambridge: Cambridge University Press, 2013).
} 
intellectuals of the Club of Committed Non-Party Members (KAN).$^{60}$ Founded in the spring of 1968, KAN released a manifesto in May demanding increased pluralism and political freedoms:

We believe that the foundations of any modern European policy lie in the idea of human and civil rights and civil equality, anchored in the revolutionary declaration of human rights, which covers both the human being and the citizen, and which is today enshrined in the UN Declaration on Human Rights. ${ }^{61}$

The aim of KAN's 3,00o members was not to completely abolish socialism, but "to combine democratic socialism with the noble program of individual freedom." Although KAN tied human rights to European identity and individual rights, as did Western European anti-communists, it regarded "capitalism, fascism, and Stalinism" as equally "dehumanizing forces," which were contrary to the "democratic endeavors of the Czech and Slovak peoples." ${ }^{2}$ Although the group cited the UDHR, it made no mention of the more recently crafted UN Human Rights Covenants or the International Year that its government was currently celebrating.

In the Soviet Union, by contrast, a small group of activists specifically latched onto the International Year of Human Rights as an anchor for its protests. A group of dissidents founded a self-published samizdat journal called Chronicle of Current Events in April 1968 to document state abuses, particularly inspired by the "trial of the four" - the prosecution of Yuri Galanskov, Alexander Ginzburg, Alexey Dobrovolsky and Vera Lahkova for "anti-Soviet agitation." The cover of the first issue had the header "International Year of Human Rights in the Soviet Union," and each issue thereafter cited Article 19 of the UDHR guaranteeing "everyone has the right to freedom of opinion and expression." Clearly influenced by Soviet propaganda, which omitted the UssR's abstention on the Universal Declaration in 1948, the Chronicle published an open letter which claimed that the USSR was bound to follow

6o Czechoslovakian socialist reformers did, however, strongly emphasize the necessity of new forms of law as a means of ordering and retraining arbitrary action by the Party, which provided an important step towards the human rights activism of the 1980s. See Kopeček, M. "The Socialist Conception of Human Rights and its Dissident Critique. Hungary and Czechoslovakia 196os-198os." East Central Europe 46 (2-3) (2019).

61 Navratil, J. The Prague Spring 1968: A National Security Archive Documents Reader (Central European University Press, 1998), ${ }^{56-57 .}$

62 Ibid. 
the rights of the UDHR "since [Soviet delegate Andrei] Vyshinskii signed it in the name of our state." 63 The group did not spark widespread dissent, but it demonstrated the extent to which already in 1968, the idea of human rights as a norm endorsed by the state had begun to trickle down into broader Soviet society. ${ }^{64}$

Meanwhile in the GDR, the use of human rights for protest came from the church, not the intelligentsia. In comparison with the 1949 Constitution, the new "socialist constitution" actually decreased the number of explicit basic rights protecting religious freedom from eight to one. ${ }^{65}$ East German church leaders turned to the Universal Declaration of Human Rights to make the case for the preservation of these rights and cited Article 18 on religious freedom. While church officials in the GDR had on occasion used the term human rights to protest suppression of church privileges, it now became central to their resistance to the constitutional changes. The Catholic Archbishop of Berlin wrote to the Constitutional Commission arguing that "the redesign of the Constitution is neither consistent with universal human rights nor an advance from the Constitution of 1949." The Archbishop cited Ulbricht's New Year's Address mentioning the International Year of Human Rights and claimed that the elimination of the right to religious freedom that had been granted by the old constitution was a direct attack on the church. He demanded the restoration of rights to freedom of religious practice and belief, since "only under these conditions can the Church carry out its activities in true freedom and serve the common good. And only under these conditions can the basic rights as expressed in Article 18 of the Universal Declaration of Human Rights of the United Nations be realized."66 The Protestant bishops of East Germany soon joined in condemning the elimination of protections of religion in similar terms, asking that "the draft includes the statement that that the rules of international law occupy an important place in the Constitution," in order to properly honor the International Year of Human Rights. ${ }^{67}$

63 Quoted in R. Horvath. "Breaking the Totalitarian Ice: The Initiative Group for the Defense of Human Rights in the UssR." Human Rights Quarterly 36 (1) (2014), 153.

64 On the impact of the Chronicle, see Nathans, B. "The Dictatorship of Reason: Aleksandr Vol'Pin and the Idea of Rights under 'Developed Socialism.'” Slavic Review 66 (4) (2007), 630-63.

65 Allinson, M. Politics and Popular Opinion in East Germany 1945-1968 (Manchester: Manchester University Press, 2000), 142-43.

66 BArch-Lichterfelde DY 30/ IV A2/13/46 Alfred Bengsch to Ulbricht (5 February 1968) 1-4.

67 Evangelical Central Archive (Evangelisches Zentralarchiv) 104/687 Noth et al. to Ulbricht (February 15, 1968), 1. 
Rather than cracking down on this dissent, the SED aimed to persuade. In the SED national newspaper Walter Ulbricht declared: "I can only repeat that religious freedom as it currently exists, will continue to exist and there is no intention to change that." ${ }^{68}$ In spite of this, East German Christians flooded the Constitutional Commission with letters demanding the restoration of the 1949 constitutional protections for religion. Almost half of the more than 12,000 pieces of mail received by the commission concerned religious freedom and several hundred more on educational rights also dealt with religious schooling. ${ }^{69}$ The human rights language contained in most of these petitions was copied directly from the statements of the bishops, and SED officials noted that many of the letters from citizens regarding religious freedom had been copied from each other even down to identical typographical errors in some cases. ${ }^{70}$ Many petitioners explicitly cited the International Year since the UN commemoration gave leverage for demanding human rights without also attacking socialism or the right of the SED to rule in the GDR. Instead they asked for space for the Christian world-view within the socialist system in accordance with UN norms, which the SED had already endorsed. These letters framed human rights as fully compatible with state socialism, and most letters argued that they would be forced to vote against the constitution only if the SED rejected its own Christian citizens.

In the end, however, there was little in the transformative "boomerang effect" that could be observed across the Eastern Bloc in 1968. In Czechoslovakia, the activists who spoke of human rights were crushed alongside the rest of the reformers of the Prague Spring when the Warsaw Pact invaded in August 1968 and KAN was formally banned the following month. Soviet dissidents would continue their activities and form the Initiative Group for Human Rights the following year - the first such organization in the Eastern Bloc. ${ }^{71}$ This handful of dissidents remained, however, politically marginal and posed no serious threat to Soviet authority. In the GDR, the protests by Christians were conducted out of sight of the international media and once SED authorities compromised by including one more constitutional right protecting religious freedom, church leaders came around and encouraged their parishioners to vote for the new socialist constitution, which they did in higher numbers than in most elections. In the end, the reactions of these groups did little to dissuade state socialist authorities from the conviction that human rights politics was

\footnotetext{
68 "Walter Ulbricht beantwortet Fragen." Neues Deutschland (February 16, 1968), 4.

69 BArch NY $4192 / 111$ Gliederung der Vorschläge nach Artikeln des Verfassungentwurfs.

$70 \quad$ BArch DY 30/IV 2/1/373 Bericht der Kommission über die Verfassung der DDR, 118.

71 Horvath, "Breaking the Totalitarian Ice."
} 
on their side, especially since self-determination and anti-colonialism still retained primacy on the international stage.

\section{Conclusion}

The Eastern Bloc states faced little blowback at home as a result of their endorsement of the 1966 Human Rights Covenants and relatively minimal criticism for their domestic political and social system at the United Nations during the International Year in spite of the invasion of Czechoslovakia. For state socialist elites, human rights were not a threat to their revolutionary project, but now an essential element of global socialism. Twenty years after abstaining on the Universal Declaration as a Bloc, the International Year of Human Rights was crucial in normalizing human rights discourse and politics in the eyes of Eastern Bloc elites, who had previously been skeptical of such language, even if they had been willing at times to deploy it diplomatically against the West. Now in the 1970s, the Eastern Bloc's claims to represent the vanguard of a global movement for emancipation and anti-imperialism was closely intertwined with the politics of human rights. In 1973 , shortly before the $25^{\text {th }}$ Human Rights Day, the Soviet Union, in partnership with Guinea and Nigeria, spearheaded the passage of the International Convention on the Suppression and Punishment of the Crime of Apartheid. ${ }^{72}$ In that same year, the GD R finally joined the UN and was also able to sign the UN human rights covenants of 1973 - reiterating its support for these norms, which had also been part of the Basic Treaty with West Germany the year before. During this time, Eastern Bloc negotiators agreed to the inclusion of human rights in the Statement of Principles of the Helsinki Accords, so long as they conformed to the terms of the UN covenants, which all of the state socialist signatories had already agreed to. Not only did socialist negotiators assume they would be protected by the principle of selfdetermination and state sovereignty, so too did most of their Western counterparts, who believed that the human rights provisions would ultimately never be realized behind the Iron Curtain. ${ }^{73}$

The Eastern Bloc's embrace of human rights politics was not just the result of Western pressure, but also stemmed from a positive embrace of the UN human rights system in the late 1960s. The International Year of Human

\footnotetext{
72 Burke, R. "Human Rights Day 1973: The 'Liberation' of the Universal Declaration." Humanitarianism \& Human Rights. See https://hhr.hypotheses.org/320.

73 Suri, J. "Détente and Human Rights: American and West European Perspectives on International Change." Cold War History 8 (4) (2008), 527-45.
} 
Rights created an institutional anchor for the Eastern Bloc's integration into the international human rights system and provided the basis for a transition from a rhetorical to an ideological commitment to human rights. While this engagement with the international human rights system would later bolster domestic dissidents and opposition, in 1968, there was a window in which it appeared to state socialist elites as though they were on the winning side of history and that the cause of human rights and socialism were one and the same. The International Year of Human Rights was thus crucial in reorienting the disposition of Eastern Bloc elites, laying the groundwork for the diplomacy of the 1970s, and providing an indigenous discourse of rights that could be appropriated by reformers and dissidents alike in the 1980 s. 